\title{
Treatment with embryonic stem-like cells into osteochondral defects in sheep femoral condyles
}

\author{
Susanna Pilichi ${ }^{1}$, Stefano Rocca ${ }^{2 *}$, Roy R Pool ${ }^{3}$, Maria Dattena', Gerolamo Masala ${ }^{2}$, Laura Mara ${ }^{1}$, Daniela Sanna', \\ Sara Casu ${ }^{1}$, Maria L Manunta ${ }^{2}$, Andrea Manunta ${ }^{4}$ and Eraldo Sanna Passino ${ }^{2}$
}

\begin{abstract}
Background: Articular cartilage has poor intrinsic capacity for regeneration because of its avascularity and very slow cellular turnover. Defects deriving from trauma or joint disease tend to be repaired with fibrocartilage rather than hyaline cartilage. Consequent degenerative processes are related to the width and depth of the defect. Since mesenchymal stem cells (MSCs) deriving from patients affected by osteoarthritis have a lower proliferative and chondrogenic activity, the systemic or local delivery of heterologous cells may enhance regeneration or inhibit the progressive loss of joint tissue. Embryonic stem cells (ESCs) are very promising, since they can self-renew for prolonged periods without differentiation and can differentiate into tissues from all the 3 germ layers. To date only a few experiments have used ESCs for the study of the cartilage regeneration in animal models and most of them used laboratory animals. Sheep, due to their anatomical, physiological and immunological similarity to humans, represent a valid model for translational studies. This experiment aimed to evaluate if the local delivery of male sheep embryonic stem-like (ES-like) cells into osteochondral defects in the femoral condyles of adult sheep can enhance the regeneration of articular cartilage. Twenty-two ewes were divided into 5 groups $(1,2,6,12$ and 24 months after surgery). Newly formed tissue was evaluated by macroscopic, histological, immunohistochemical (collagen type II) and fluorescent in situ hybridization (FISH) assays.
\end{abstract}

Results: Regenerated tissue was ultimately evaluated on 17 sheep. Samples engrafted with ES-like cells had significantly better histologic evidence of regeneration with respect to empty defects, used as controls, at all time periods.

Conclusions: Histological assessments demonstrated that the local delivery of ES-like cells into osteochondral defects in sheep femoral condyles enhances the regeneration of the articular hyaline cartilage, without signs of immune rejection or teratoma for 24 months after engraftment.

Keywords: Articular cartilage, Embryonic stem-like cell, Fluorescent in situ hybridization, Osteochondral defect, Sheep

\section{Background}

Articular cartilage has a poor intrinsic capacity for regeneration because of its avascularity and very slow turnover both at the cellular and molecular levels. As consequence, defects occurring as a result of trauma or joint disease tend to be repaired with fibrocartilage rather than hyaline cartilage. With time, degenerative processes frequently occur in the regenerated tissue [1-3], which may stabilize or progress in relation to 2 main

\footnotetext{
* Correspondence: rocca@uniss.it

${ }^{2}$ Department of Veterinary Medicine, via Vienna, Sassari 07100 , Italy

Full list of author information is available at the end of the article
}

factors: the width and depth of the defect. It has been demonstrated that sheep articular cartilage osteochondral defects $3 \mathrm{~mm}$ wide or less re-fill with normal hyaline cartilage, whereas wider defects are replaced by fibrocartilage which, eventually, degenerates into fibrous tissue [4]. This inferior regenerated tissue is not capable of withstanding the mechanical loads exerted on the tissue during locomotion and the result is eburnation of the subchondral bone $[4,5]$. In relation to the depth, superficial defects involving only the articular cartilage do not heal spontaneously $[1,2,6]$, while osteochondral defects, penetrating the subchondral bone and thus, gaining access to the 
mesenchymal stem cells (MSCs) that reside in the bone marrow space, can give rise to regenerated cartilage [7-9].

Surgical treatments used to stimulate cartilage regeneration, in most cases, result only in a delay in the onset of degenerative processes [10-15]. Thus, there is a search for alternative solutions, and cell engraftment is among the most advanced new technologies in cartilage regeneration [16-19]. Considering that in certain degenerative diseases, autologous stem cells are depleted and have reduced proliferative capacity and chondrogenic ability $[20,21]$, the delivery of heterologous cells may enhance regeneration or inhibit the progressive loss of joint tissue $[20,21]$. Among the several factors to be considered in the choice of the type of cells, there are the ease of harvest, the cell yield and purity and their proliferative and chondrogenic capacity [22]. Autologous chondrocyte implantation (ACI), the first technique used to repair focal cartilage defects [23-25], is associated with donor site morbidity, loss of chondrocyte phenotype upon ex vivo expansion and inferior fibrocartilage formation at the defect site [26-28]. Thus, new extracorporeal cell sources are sought, mainly stem cells. Among them, MSCs $[17,18,21,29,30]$ have the advantages of their immunoevasivity [31] and immunosuppressive effect [32,33], but they have a limited capacity for self-renewal and proliferation, and differentiation potential decreases with increasing donor age [34]. On the contrary, embryonic stem cells (ESCs) are able to self-renew for prolonged periods without differentiation and, most importantly, to differentiate into a large variety of tissues derived from all 3 germ layers [35-38]. Despite the fact that their use is complicated by immunologic incompatibility and possible development of teratomas [39-41], as well as the existence of ethical problems in human application, in the future, the establishment of ESCs lines from ungulates could allow their employment in bulk for basic research and for producing animal models of human diseases [42]. Indeed, the histological appearance of the articular regenerated tissue is essential for the validation of therapeutic interventions [9] and it is likely to be predictive of its functionality and durability [43]. Since in humans it is possible to perform only small arthroscopic sampling to evaluate the histological aspect of the regenerated tissue, deep histological studies can be performed in vivo only in animal models. To date few studies concerning cartilage regeneration have been performed in animal models in vivo [44-52] and, until recently, most of the research on stem cells has been carried out in small laboratory animals [30,53-55]. However, these species do not represent an optimal model for achieving cartilage regeneration in human. On the contrary, the larger size and weight of adult sheep, which place greater weight-bearing loads on the healing site, as well as the structural, biochemical, physiological and immunological similarities to man and the ease and low cost of their management with respect to other species, make sheep an optimal experimental model for future clinical applications in humans $[50,56]$.

The stem origin of the in situ differentiated cells in the regenerated tissue was confirmed by the FISH technique.

This experiment aims to evaluate if the treatment with ES-like cells into osteochondral defects in the medial femoral condyles of adult sheep can enhance the regeneration process of articular cartilage over a long time period, without formation of teratomas.

\section{Results}

Only 17 animals were included in the statistical analysis, because 5 sheep died from toxaemic gastroenteritis after breaking through paddock fencing and freely consuming grass covered with frost. One sheep belonging to the 24 month group died at about 12 months post-surgery, and hence was included with the 12 month group. Analysis was thus performed on 2 sheep in the 1 month group, 3 sheep each in the 2 and 6 month groups, 5 sheep in the 12 month group and 4 sheep in the 24 month group.

\section{Embryo sexing and ES-like cell characterization}

Sexing PCR allowed selection of male embryos for production of male ES-like cells. Male embryos showed 2 bands corresponding to the sex-determining region Y-linked gene (SRY) and the sheep SAT 1,114 DNA repeat unit (SAT) sequences, while female embryos showed only the band corresponding to the autosomal sequence SAT (Figure 1A). ES-like colonies demonstrated their staminality state by positive immunostaining for SSEAs monoclonal antibodies (mAbs) and positive gene expression for Oct 4, Nanog, Sox 2 and Stat 3 genes (Figure 1B, C, D, E), and their undifferentiated state by the absence of staining with any of the anti-cytokeratin-18, Fe-C6, F1-652 and FORSE-1 mAbs.

\section{Clinical assessment}

Eight sheep were moderately lame in both hind limbs the day after surgery, but they all walked normally by day 9. No further problems with locomotion were noted in any of the animals during the remainder of the study.

\section{Macroscopic assessment}

Since the interaction between time and treatment was not significant for any of the analysed variables, it was removed from the statistical model, to test the effect of the main factors (treatment and time period). No significant effect of treatment was observed in the macroscopic assessment, either in the total or in the single category scores throughout all considered time periods (from 1 to 24 months) (Table 1). However, ES samples showed higher least square means with respect to empty defects (ED) samples, both in the total macroscopic score, in 


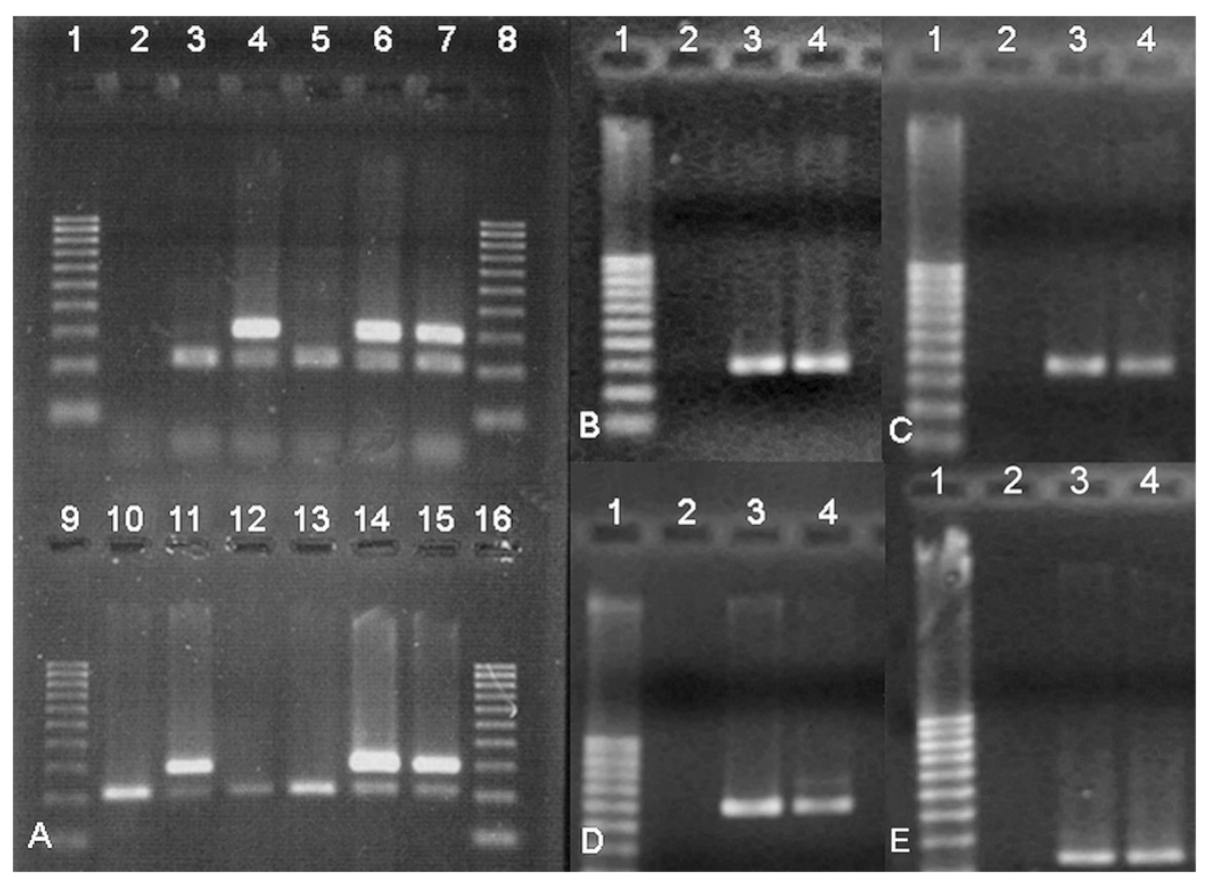

Figure 1 Embryo sex determination and ES-like colonies gene expression. A): Embryo sex determination. Lanes 1, 8, 9, 16: DNA marker 100-1000 bp ladder (Sigma); lane 2: negative control (no DNA); lane 3: female positive control (sheep oviductal cells); lane 4: male positive control (male lamb fibroblasts); lanes 5, 10, 12, 13: female embryos; lanes 6, 7, 11, 14, 15: male embryos. B,C, D, E) ES-like colonies gene expression. B) Oct4gene expression; C) Sox2 gene expression; D) Nanog gene expression; E) Stat3 gene expression. Lane 1: DNA Marker 100-1000 bp ladder (Sigma); lane 2: negative control (no cDNA); lane 3: in vitro produced sheep blastocyst, used as positive control; lane 4: ES-like cells.

the surface appearance and in the filling of the defect, while the integration of edges was slightly better in the ED animals (Table 1). For sake of clarity in the presentation of results, the interaction was maintained in the statistical model in order to estimate the least square means for each period per treatment level (Additional file 1: Table S3).

\section{Evaluation at 1 month}

The total macroscopic score showed better healing in the ES samples than in the ED. The ES samples had a better surface appearance and had greater filling with a soft, red tissue (Figure 2A) than the ED samples (Table 1), where only the bottom and the sides of the defect were covered

\section{Table 1 Least square means \pm standard error of ES and ED macroscopic scores compared from 1 to 24 months (17 ESM and 17 ED)}

\begin{tabular}{llll}
\hline Categories & & \multicolumn{2}{l}{ Treatments } \\
\cline { 3 - 4 } & ES $^{*}$ & ED $^{\dagger}$ & P value \\
\hline Total macroscopic score & $4.66 \pm 0.4$ & $3.81 \pm 0.4$ & n.s. $^{\neq}$ \\
Surface appearance & $1.51 \pm 0.2$ & $1.06 \pm 0.2$ & n.s. \\
Filling of defect & $2.09 \pm 0.2$ & $1.65 \pm 0.2$ & n.s. \\
Edges integration & $1.06 \pm 0.2$ & $1.10 \pm 0.2$ & n.s. \\
\hline
\end{tabular}

${ }^{*}$ Embryonic stem-like cells engrafted in the medial femoral condyle; ${ }^{\dagger}$ Empty defect; ${ }^{*}$ not significant. by the proliferating tissue (Figure 2E). Edge integration was absent in all samples.

\section{Evaluation at 2 months}

The overall healing process decreased in the ES samples with respect to the control group. Surface appearance showed a flat whitish tissue with a regular and smooth surface which completely filled the ES (Figure 2O), while it only partially filled the ED (Figure 2I), despite the fact that both treated and control groups showed the same least square mean in both categories. In both samples the newly proliferating tissue still lacked continuity with the host cartilage, though the ED group showed a better least square mean (Table 1 ).

\section{Evaluation at 6 months}

Both samples had opalescent-appearing regenerated tissue with extended superficial cracks (Figure $2 \mathrm{~S}$ and W), showing the same least square means in the total macroscopic score and in the filling of the defect. ES samples had slightly higher scores for surface appearance, and slightly lower scores for edge integration (Table 1).

\section{Evaluation at 12 months}

Regenerated tissue, which appeared similar to pre-existing cartilage, completely filled both defects, and was continuous with the host tissue (Figure 3A and E). All examined 


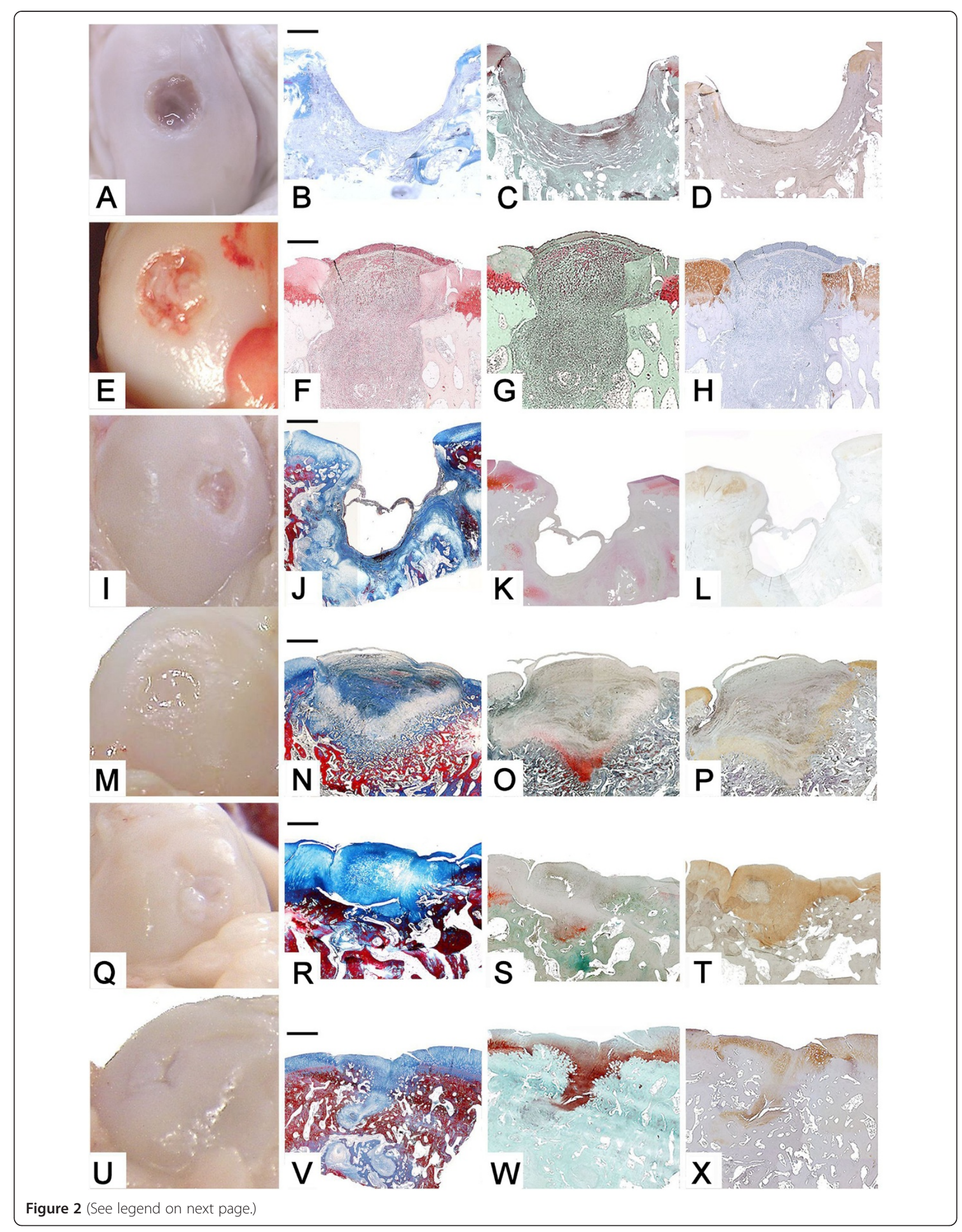


(See figure on previous page.)

Figure 2 Femur, sheep. Embryonic stem-like cells engraftment in the medial femoral condyle (ES) and empty defects (ED) at 1,2 and 6 months from surgery. A-D) ED at 1 month from surgery. E-H) ES at 1 months from surgery. I-L) ED at 2 months from surgery. M-P) ES at 2 months from surgery. Q-T) ED at 6 months from surgery. U-X) ES at 6 months from surgery. A-E-I-M-Q-U) macroscopic appearance; B-J-N-R-V) histological sections, Azan-Mallory staining. 2X magnification; bar: $1 \mathrm{~mm}$. F) Haematoxylin-eosin staining, C-G-K-O-S-W) Safranine-O staining. D-H-L-P-T-X) Collagen type II immunostaining.

categories showed higher least square means in ES samples with respect to the control group (Table 1).

\section{Evaluation at $\mathbf{2 4}$ months}

Both defects were completely filled by a newly formed tissue, smooth and white like hyaline cartilage. Edges were totally integrated with the host tissue, with the exception of one ED which showed a small fissure near the edge (Figure 3I and O). Once again, all examined categories showed higher least square means in ES samples with respect to the control group, and a slight overall decrease with respect to the 12 month time period (Table 1).

\section{Histological assessment}

As for the macroscopic assessment, the interaction between time and treatment was not significant for any of the histological variables and was removed from the model to test the effect of the main factors (treatment and time). ES performed significantly better in the total histological score $(\mathrm{p}<0.001)$ and in the filling of defect, cartilage, matrix, bone and edge categories $(p<0.05)$ with respect to $\mathrm{ED}$, while no significant differences were observed between treated and control groups in degeneration or vascularity (Table 2), though higher least square means were reached by ES samples than control (Table 2). Once again, to better clarify the evolution of the regeneration process,

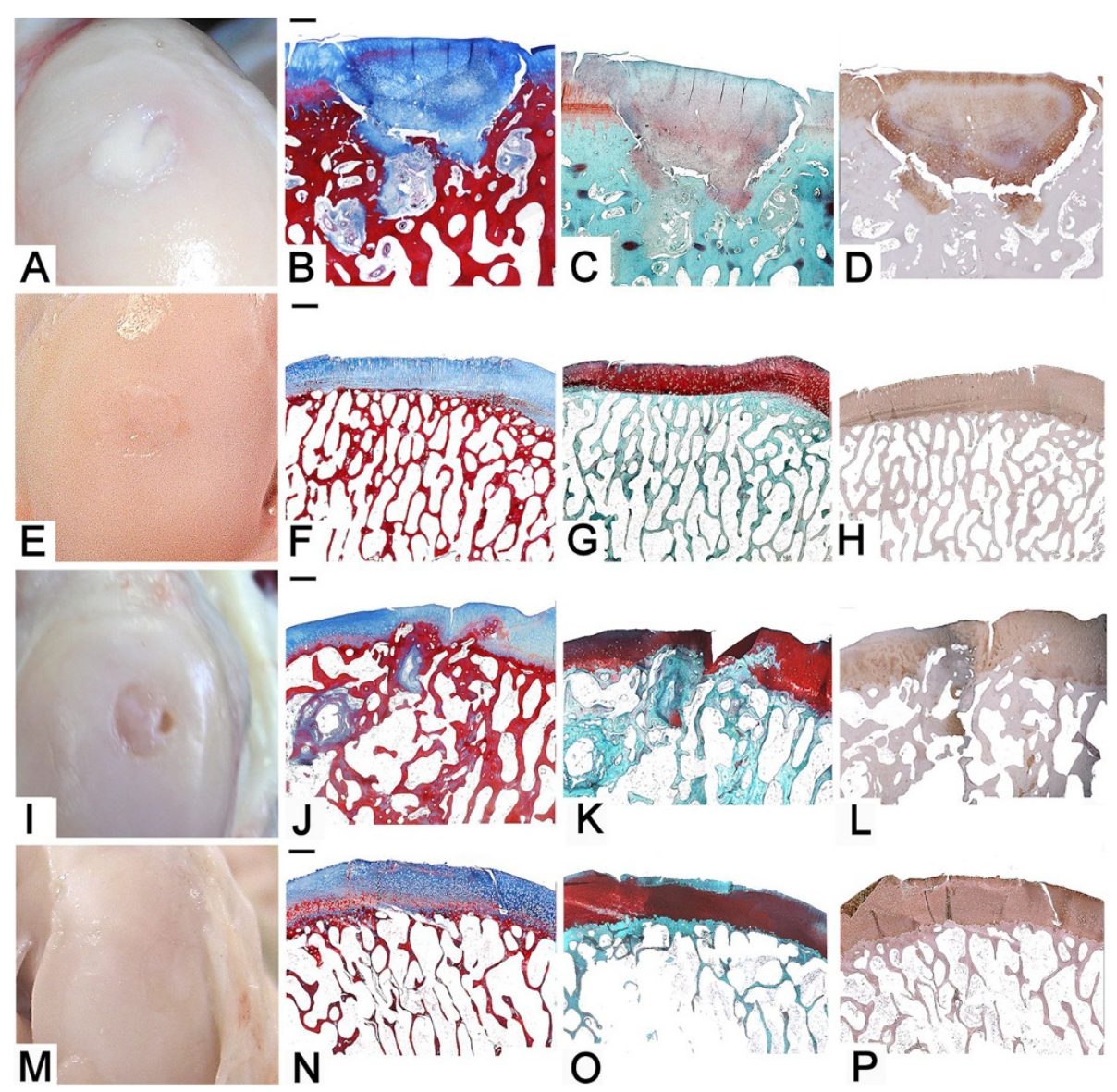

Figure 3 Femur, sheep. Embryonic stem-like cells engraftment in the medial femoral condyle (ES) and empty defects (ED) at 12 and 24 months from surgery. A-D) ED at 12 months from surgery. E-H) ES at 12 months from surgery. I-L) ED at 24 months from surgery. M-P) ES at 24 months from surgery. A-E-I-M) macroscopic aspect; B-F-J-N) histological sections, Azan-Mallory staining, 2X magnification; bar: 1 mm. C-G-K-O) Safranine-O staining. D-H-L-P) Collagen type II immunostaining. 
Table 2 Least square means \pm standard error of histological scores compared throughout all considered periods

\begin{tabular}{|c|c|c|c|}
\hline \multirow[t]{2}{*}{ Categories } & \multicolumn{2}{|c|}{ Treatments } & \multirow{2}{*}{$\begin{array}{l}P \\
\text { value }\end{array}$} \\
\hline & $\mathrm{ES}^{*}$ & $\mathrm{ED}^{\dagger}$ & \\
\hline total histological score & $36.33 \pm 1.1$ & $30.41 \pm 1.1$ & $<0.001$ \\
\hline filling of defect & $1.65 \pm 0.1$ & $1.22 \pm 0.1$ & $<0.05$ \\
\hline cartilage & $6.75 \pm 0.4$ & $5.20 \pm 0.4$ & $<0.05$ \\
\hline matrix & $5.83 \pm 0.4$ & $4.46 \pm 0.4$ & $<0.05$ \\
\hline bone & $4.57 \pm 0.2$ & $3.90 \pm 0.2$ & $<0.05$ \\
\hline edges & $1.81 \pm 0.2$ & $1.13 \pm 0.2$ & $<0.05$ \\
\hline degeneration & $10.86 \pm 0.2$ & $10.61 \pm 0.2$ & n.s. $^{\ddagger}$ \\
\hline vascularity & $4.86 \pm 0.5$ & $3.89 \pm 0.5$ & n.s. $^{\ddagger}$ \\
\hline
\end{tabular}

"Embryonic stem-like cells engrafted in the left medial femoral condyle;

${ }^{+}$Empty defect created in the right medial femoral condyle. ${ }^{\ddagger}$ not significant.

the least square means for each period and treatment were calculated (Additional file 1: Table S4).

\section{Evaluation at 1 month}

Proliferating granulation tissue rich in vessels and fibroblasts completely filled the cavity in the ES samples, while it covered the bottom and the walls only of the ED samples. Foci of endochondral ossification were detected at the bottom of the ES samples; there was no integration between new and host tissue, despite their close proximity. Regenerated tissue was negative for proteoglycans and collagen type II production in both groups (Figure 2B, C, D and F, G, H). Higher least square means were reached by ES samples with respect to controls in the total histological score, filling of defect, cartilage, matrix and degeneration categories, while they were equal in both treated and control groups in bone and edges categories (Additional file 1: Table S4).

\section{Evaluation at 2 months}

ES were superficially filled by fibrous tissue and by subchondral ossification at the bottom, while ED were less completely filled and one sample showed a deep hole covered by a thin bridge formed by the tangential layer. Integration between new and host tissues was present only at one edge in the ES. An initial production of proteoglycans and a mild staining for collagen type II were detectable at the bottom of both defects, while the fibrous tissue in the top was negative (Figure $2 \mathrm{~L}, \mathrm{M}, \mathrm{N}$ and $\mathrm{P}, \mathrm{Q}, \mathrm{R})$. Higher least square means were reached by ES samples with respect to controls in all the histological categories (Additional file 1: Table S4).

\section{Evaluation at 6 months}

Both samples contained fibrocartilage in the superficial part. There was woven bone with foci of subchondral ossification at the bottom of the ED samples. Cartilage clefts and small subchondral cysts were sometimes present. Clefts were deeper and localized at the edges with surrounding degenerated matrix in the ED, in which continuity between tangential layer proliferation and subchondral ossification was sometimes interrupted. Proteoglycans were conspicuous in the ES, especially in the deeper part of fibrocartilage, while an initial production was detected within the foci of subchondral ossification in the ED. A marked staining for collagen type II was present in the regenerated tissue of both samples, together with some negative areas in the middle and deeper parts (Figure 2T, U, V and X, Y, Z). Higher least square means were reached by ES samples with respect to controls in the total histological score, matrix, bone and edges categories, while they were equal in both ES and ED groups in the filling of defect category, and slightly lower in ES in respect to ED in the cartilage and degeneration categories (Additional file 1: Table S4).

\section{Evaluation at 12 months}

ES samples showed immature hyaline cartilage and lamellar bone, and the ED group had immature hyaline cartilage spaced out by fibrocartilage and woven bone, where continuity between tangential layer proliferation and subchondral ossification was often absent, and only one edge was integrated. ED samples sometimes showed deep cracks involving the whole depth of the cartilage. Proteoglycan staining was strong in the ES group and minimal in the ED, while collagen type II immunostaining was intense in both groups, with some negative areas in the centre of the regenerated cartilage in the ED animals (Figure 3B, C, D and $F, G, H)$. Higher least square means were reached by ES samples with respect to controls in all the histological categories (Additional file 1: Table S4).

\section{Evaluation at $\mathbf{2 4}$ months}

The appearance of the newly formed tissue in ES animals was comparable to mature hyaline cartilage, lying on a well-reconstituted subchondral plate formed by lamellar bone; integration between regenerated and host tissue was present at both edges and mild to moderate articular deterioration was seen (Figure 3P). The healed cartilage consisted of a superficial zone with proliferating germinal cells and collagen fibres distributed parallel to the articular surface, overwhelming an area rich in chondrocytes organized in large clones, and a transitional zone characterized by palisading chondrocytes and spring-shaped arrangements of collagen fibres. Subjacent to this was a radial zone with hypertrophic chondrocytes and collagen fibres arranged perpendicular to the articular surface, and a deep zone with calcification and formation of tidemark, still discontinuous (Figure 3P and Figure 4A). On the contrary, ED were filled by immature hyaline cartilage in the upper part and woven bone at the bottom, 


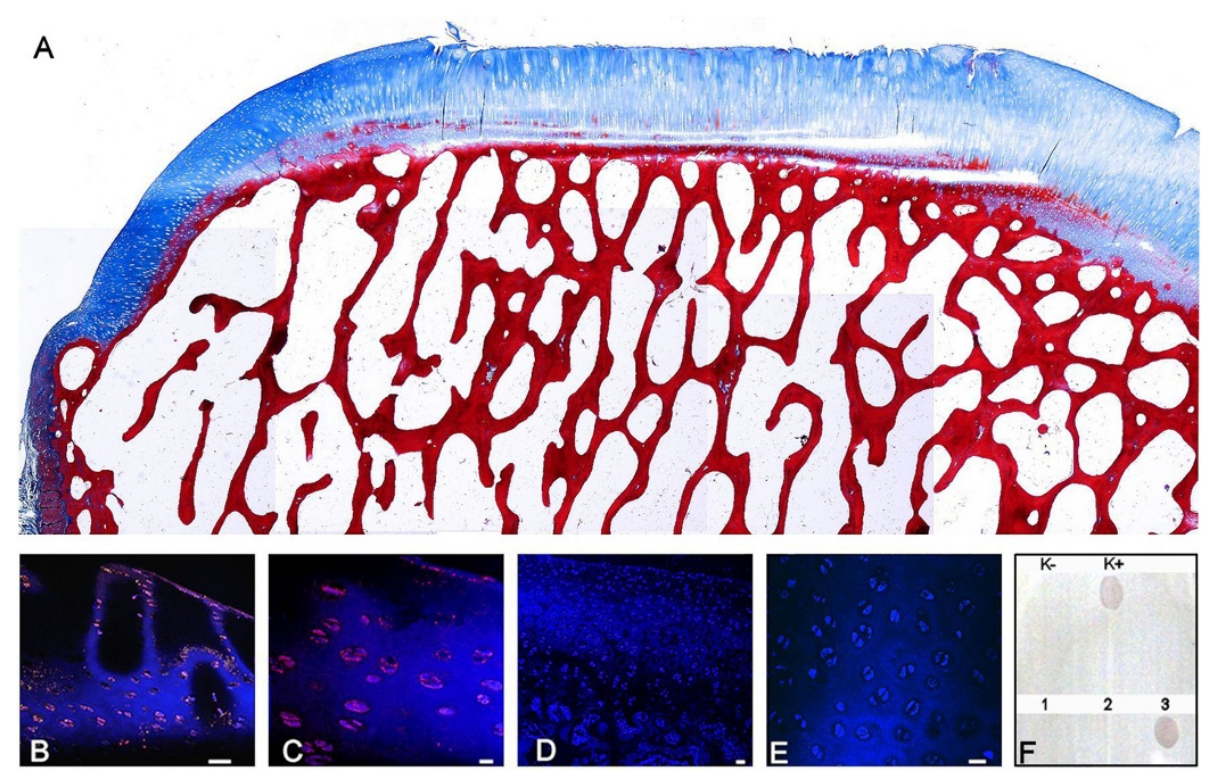

Figure 4 Femur, sheep. Embryonic Stem-like cells engraftment at 24 months from surgery. A) Histological aspect: Azan-Mallory staining; $2 \times$ magnification; bar: 500 m. B) Fluorescent in situ hybridization (FISH): positive signals in chondrocytes derived from ES-like cells. 40x magnification; bar: $50 \mu \mathrm{m}$. C) Same field, 60× magnification; bar: $10 \mu \mathrm{m}$. D) Normal female adult articular cartilage from the right lateral femoral condyle (negative control). No signals are detected within chondrocytes. 20x magnification; bar: $30 \mu \mathrm{m}$. E) Same field, 40x magnification; bar: $20 \mu \mathrm{m}$. F) Dot-Blot test with SRY probe. K-: spot female sheep fibroblasts (negative control), K+: spot male sheep fibroblasts (positive control), 1-2: spot female ES-like cells, 3: spot male ES-like cells.

where moderate subchondral cysts were sometimes detected (Figure 3L). Intense proteoglycan and collagen type II staining was detected in the newly formed cartilage (Figure 3M, N and Q, R). Higher least square means were reached by ES samples with respect to the control group in all the histological categories (Additional file 1: Table S4).

\section{FISH detection}

Dot-Blot showed positive spots with both DNA derived from ES-like cell samples and male fibroblasts (positive control), whereas female fibroblasts DNA (negative control) was negative, confirming the specificity of the chosen probe (Figure 4A). FISH showed positive intranuclear signals only in the ES-like derived cells found in the newly formed tissue at all-time points, while controls were always negative (Figure 4B, C, D, E).

\section{Discussion}

In this study ES showed significantly better histological evidence of healing when compared to ED in most of the examined categories. To our knowledge, this is the first time that ES-like cells have been engrafted in sheep and then evaluated out to 24 months post-surgery. Previously, engraftments had been assessed at a maximum period of 18 months in sheep [4], 12 months in goats [21], 8 months in horses [18] and 6 months in laboratory animals [30,53-55].

Sheep have been shown to be a valid model for human translational research when compared with laboratory animals, due to the increased stifle size, less effective native cartilage regeneration and longer lifespan. Moreover, a recent study comparing the differences in geometry and biomechanical properties of human, porcine, bovine and ovine articular cartilage, found that human cartilage had a significantly larger flexibility with respect to porcine and bovine cartilage, but not to ovine cartilage [57]. In addition, from the regulatory point of view, the ovine model is one of the suggested large animal models for pre-clinical studies [48]. However, in previous studies in small ruminants (sheep $[4,13,14,49,52]$ and goats $[5,7,21]$ ), most animals were euthanized at 6 months, paralleling the time frame of experiments in laboratory animals. According to the authors, this is insufficient time to observe complete regeneration in large animals. Schneider-Wald [58] states that the follow-up period for assessment of the effectiveness of cartilage regeneration is 12 months. Moreover, in sheep, several authors $[46,47,49-51]$ worked with chondral defects, despite the fact that this type of defect can't heal spontaneously $[1,2,6]$. Most of the experiments performed in sheep employed surgical techniques only without the use of cells $[4,13,52,59]$ and, even when stem cells were used, the methods of delivery to the cartilage varied from direct injection to implantation with a large variety of scaffolds [60]. For these reasons, it is difficult to compare results obtained in this experiment with previously reported trials.

Sexing PCR performed on trophoblastic cells lysed during the immunosurgery procedure confirmed that 
the choice of the sex-determining region Y-linked gene sequence (SRY) as a marker for ES-like cells was effective and reliable for this purpose [61]. To detect the stem origin of differentiated cells, several authors $[21,49,62]$ employ green fluorescent protein (GFP) transduced cells. However, this procedure is applicable only on cells that can be expanded ex-vivo in large amounts, such as MSCs $[21,49]$ and rodent ESCs [62]. On the contrary, ungulate embryonic stem cells show an early in vitro differentiation $[42,63]$, which does not allow production of the needed amount of cells for the application of this technique. To overcome this problem, the authors engrafted only male ES-like cells in female sheep, and the SRY sequence was used as a marker for the FISH technique, which allowed to confirm the stem origin of differentiated cells.

ES-like colonies were positive for the SSEAs mAbs and the gene expression for Oct 4, Nanog, Sox 2 and Stat 3 genes, and negative for any of the mAbs marking the differentiated state, demonstrating that the engrafted cells were stem cells, in agreement with others [64-76]. The low number of ES-like cells engrafted was due to the early in vitro differentiation of sheep ES-like cells, as mentioned above $[42,63]$ which does not provide the higher numbers of cells used in other studies $[18,30,62]$. This forced us to use cells derived from the first passage, when they were still in an undifferentiated state. The establishment of ES cell lines of domesticated ungulates is of interest both for basic research, such as the study of comparative embryology and the comprehension of the mechanisms of cell biology related to stem cell maintenance and differentiation [42], and applied research, such as the creation of models of human genetic diseases and cell transplantation therapy [42].

The lateral para-patellar approach was shown to be reproducible in a standardized fashion and reliable for long-term success of the cell therapy. Indeed, all animals walked normally 9 days after surgery and no signs of major wound infection or limited range of motion were detected, similar to previous reports in sheep $[4,13,52]$, goats [5,21] and rabbits [30,55]. Medial patellar dislocation was necessary to reach the medial femoral condyle. Lateral access guarantees greater resistance of the sutures in the various layers of the closure, thanks to the presence of the fascia lata. Arthroscopy was not used because it did not allow the deposition of the cell-fibrin graft in the defect. The surgeons noted that this technique was quite invasive and could have negatively influenced the results, due to the loss of synovial fluid during the surgical procedure and consequent dehydration of articular cartilage. These problems have been overcome in later studies (data not shown) with the introduction of the mini-arthrotomy technique. Particular attention has been paid to meticulously removing all calcified cartilage between the tidemark and the osteochondral junction, according to Hurtig [77]. This cartilage layer appears to be an effective barrier to the invasion of the blood and precursor cells from the subchondral bone, resulting in a lack of attachment of the regenerated tissue to subchondral bone [77].

No significant macroscopic differences were observed between ES and ED samples. This is probably because of the absence of the assessment of transverse sections, perpendicular to the articular surface and about 1-2 cm deep, which could have allowed evaluation of the quality of the newly formed tissue deep in the samples, together with the detection of subchondral cysts. In any case, this experiment demonstrates that, in sheep, tissue resembling cartilage appears only at 6 months post-surgery, as noted by other authors [4,78], and integration of edges is complete at 12 months, as reported by Akens [4] but in contrast to the findings of Schleicher [78]. It is interesting to note that at 24 months there was a slight overall decrease in the regeneration process in both groups (more marked in the ED group) as compared to 12 months.

The ES group performed significantly better in most categories of histological assessment with respect to ED. Beginning at the earliest time points, this group had more normal architecture and a better quality of matrix in the newly formed cartilage, similar to the findings of Akens [4]. These findings suggest the enhancement of the physiological regeneration process exerted by ES-like cells, probably by means of paracrine signals $[1,79]$. Several authors $[8,17,19,80-83]$ outline the complex interplay existing between proteoglycans and collagen type II, the two most important components of the hyaline cartilage matrix: the collagen fibrils serve to anchor the proteoglycan matrix and contribute to resisting extrinsic forces during loading and the intrinsic swelling that occurs within the proteoglycan domain, while proteoglycans are responsible for the generation of a hydrostatic pressure within cartilage matrix, which allows it to counteract the loads transmitted to it from the long bones during normal joint articulation.

Tidemark appeared at 12 months after surgery, without statistically significant differences between treatment groups. It was still discontinuous in most of samples at 24 months post surgery, suggesting that the regenerative process was not yet complete. The presence of the tidemark is an important finding: it has been reported that this calcification front is in a state of dynamic equilibrium, where factors promoting mineralization are probably counterbalanced by substances that inhibit or limit the extent of calcification, and this process of active calcification and subsequent endochondral ossification seems to be integral to the shape of the joint and, therefore, to the distribution of load [84].

In relation to bone remodeling, lamellar bone was detected 12 months after surgery in most of the ES 
samples, while ED controls showed mostly woven bone. This last finding is in contrast with Jackson [7] who, in empty defects in goats at 13 months, found sclerotic bone surrounding the defect adjacent to subchondral areas, sparse bone resorption and marked endochondral bone formation, probably because of the difference in the anatomy and ambulation between sheep and goats. These results further confirm the benefits that occurred in the defects treated with ES-like engraftments, considering that a good remodeling of subchondral bone provides the right biomechanical support for the hydrostatic compression in the cartilage, which is of critical importance for the differentiation of hyaline cartilage $[8,81]$.

ES samples showed very good integration between the newly formed cartilage and the host tissue as compared to ED samples, particularly evident at 12 and 24 months. These findings, similar to those reported by Akens [4], seem likely to be predictive of the functionality and durability of the regenerated tissue. It is well known that the gap between implant and host tissue is responsible for the initiation of cartilage degeneration, as a result of a penetration of the synovial fluid into the host-graft interface which results in resorption within the subchondral bone area and cyst formation $[4,7,59]$.

Mild to moderate signs of articular deterioration (delamination, fibrillation or clefts of the cartilage surface) predominated in the ED samples. Subchondral bone cysts, varying from mild to severe, were detected in both groups, with a higher incidence at 6 months, similar to previously published reports $[4,7,59]$. This could be due to the particular texture of the regenerated tissue at this time point, enough hard to allow the penetrating synovial fluid to reach high pressures but, at the same time, too soft to counteract it, with consequent collapse of the walls and enhancing of the cyst formation.

No signs of immune rejection or teratoma occurred in any of the ES-like engraftments, despite the fact that engrafted animals were not immunosuppressed. It could be due to the osteochondral microenvironment, which may have forced the implanted cells to differentiate toward the osteogenic and chondrogenic lineage [39-41,85] or to the small number of cells implanted [16]. A recent study [62] hypothesizes that cycling loading may affect the differentiation of stem cells in osteochondral defects to the osteocyte and chondrocyte phenotypes.

\section{Conclusions}

Heterologous embryonic stem-like cells implanted into osteochondral defects in sheep femoral condyles enhanced the regeneration of the articular hyaline cartilage, without the occurrence of immune rejection or teratoma formation even at 24 months post-surgery. These findings are encouraging for safe translation to human clinical trials.

\section{Methods}

\section{Ethics statement}

The animals were maintained and treated in accordance with Legislative Decree 116/92 guidelines based on European Directive 86/609/EEC. Animal welfare was routinely checked by veterinarians from VTH (Veterinary Teaching Hospital) of the Department of Veterinary Medicine and every effort was made to minimize the number of animals used and their suffering (see ARRIVE checklist in Additional file 2). The experimental protocols were approved by the Ethical Committee of the University of Sassari and by the veterinary control officers of animal protection in experimental and clinical studies conducted at the University of Sassari (Auth. of 06/06/2012).

If not indicated otherwise, all chemicals were purchased from Sigma-Aldrich.

\section{Experimental design}

Twenty-two Sarda ewes, about 5.5 years old and weighing approximately $45 \mathrm{~kg}$, without muscular-skeletal pathologies, were used in this experiment. Sheep were divided into 5 groups which were euthanized at 1, 2, 6, 12 and 24 month post-surgery, respectively. Each group was composed of 4 sheep with the exception of the 24 month group, where 6 sheep were allotted to account for possible deaths during the study period. ES-like cells were engrafted in the osteochondral defect created in the left medial femoral condyle (ES), while the identical defect created in the controlateral stifle joint was left untreated (ED) and served as a control. Thus, a total of 44 defects were created: $22 \mathrm{ES}$ and $22 \mathrm{ED}$ (Table 3).

In vitro embryos production, embryo sexing, ES-like cell production and characterization

About 100 embryos at the blastocyst stage were produced following in vitro maturation, fertilization, culture

Table 3 Experimental design

\begin{tabular}{|c|c|c|c|}
\hline Period-groups & $\mathrm{N}^{\circ}$ of sheep & $\begin{array}{l}\text { Stifle joint (medial } \\
\text { femoral condyle) }\end{array}$ & Treatment \\
\hline \multirow[t]{2}{*}{1 month } & 4 & Left & $\mathrm{ES}^{*}$ \\
\hline & & Right & $\mathrm{ED}^{\dagger}$ \\
\hline \multirow[t]{2}{*}{2 months } & 4 & Left & ES \\
\hline & & Right & ED \\
\hline \multirow[t]{2}{*}{6 months } & 4 & Left & ES \\
\hline & & Right & $\mathrm{ED}$ \\
\hline \multirow[t]{2}{*}{12 months } & 4 & Left & ES \\
\hline & & Right & ED \\
\hline \multirow[t]{3}{*}{24 months } & 6 & Left & ES \\
\hline & & Right & ED \\
\hline & 22 & & 44 \\
\hline
\end{tabular}

"ES-like engraftment in the medial femoral condyle defect; ${ }^{\dagger}$ Empty Defect. 
and vitrification procedures, as previously described [86]. Since the presence of the SRY sequence was used as a marker to detect male ES-like cells in the regenerated tissue, only male embryos were selected to produce ESlike cells, by means of a duplex PCR [61]: the 2 pairs of primers (Life Technologies) identified both the SRY gene sequence of male embryos (SRY-fwd 5' -CTCAGCAAAG CACACCAGAC-3', SRY-rev-5'-GAACTTTCAAGCAG CTGAGGC-3'), and the SAT sequence in both sexes (SAT-fwd 5' -TGGAAGCAAAGAACCCCGCT-3', SATrev 5'-TCGTGAGAAACCGCACACTG-3'). SAT was used as positive control for the reaction. Male lamb fibroblasts and sheep oviductal cells were used as positive and negative controls, respectively. Amplification products were analysed on $2 \%$ agarose gel stained with ethidium bromide and observed under ultraviolet light.

The inner cell mass (ICM) from each numerically identified male embryo was isolated by immunosurgical complement mediated lysis of trophoblastic cells and separately cultured on a mouse fibroblast feeder layer for 5 to 6 days [65], to obtain ES-like colonies. These were characterized both immunocytochemically, by detection of surface antigens for staminality SSEA-1, SSEA-3 and SSEA-4 (Developmental Studies Hybridoma Bank - DSHB, University of Iowa, Iowa City, IA) [65] (Table 4) and by assessment of the gene expression of Oct 4, Nanog, Sox 2 and Stat 3 genes [68]. To assess the absence of differentiation towards germinal layers, cytokeratin, early mesoderm, embryonic myosin and neural precursor cell specific primary mAbs (DSHB) were used [65] (Table 4).

\section{Preparation of cells for engraftment and surgical procedures}

For each graft, 2 to 3 male ES-like colonies were harvested from the Petri dish, disaggregated using trypsin and pooled together, as previously described [16]. About 500,000 cells were embedded in $60 \mu \mathrm{l}$ of fibrin glue and engrafted into the cartilage defect.

All animals were given a general health examination, dewormed and had their claws inspected prior to the experimental surgery. After sedation (Diazepam $0.4 \mathrm{mg} / \mathrm{kg}$ IV) and sacro-coccigeal (S4-Co1) epidural anaesthesia
(Lidocaine $2 \mathrm{mg} / \mathrm{kg}$ ), the induction of the anaesthesia was performed with Ketamine ( $3 \mathrm{mg} / \mathrm{kg}$ IV) and maintained with Ketamine $\left(3 \mathrm{mg} \mathrm{kg}^{-1} \mathrm{~h}^{-1}\right)$ and Fentanyl $\left(8 \mathrm{mcg} \mathrm{kg}^{-1} \mathrm{~h}^{-1}\right)$. A lubricated stomach tube of $1 \mathrm{~cm}$ of inner diameter was inserted into the rumen to prevent bloating. The animal was positioned in dorsal recumbency in a cradle for thoracic containment, leaving posterior limbs free. After disinfection and preparation of the surgery field, with the knee placed in maximum flexure, a para-patellar arthrotomy of both stifle joints was performed using a lateral approach and medial patellar dislocation, to expose the articular surface of the weight-bearing area of the medial femoral condyle. A cranio-lateral cutaneous incision, of about $8 \mathrm{~cm}$ in length, was performed over the rotula, followed by subcutaneous tissue incision to visualize the septum between the superficial lamina and the fascia lata and the biceps-femoral muscle proximally and the retinaculum distally. Finally, the incision of the articular capsule allowed access to the joint. A full-thickness defect was made in the articular cartilage using a $6 \mathrm{~mm}$ diameter punch to mark off the edges of the defect and to cut down into the cartilage until the calcified portion was reached. A curettage was then performed by using a little Williger spoon to remove cartilage debris. To make the defect walls perfectly perpendicular to the articular surface and to remove the whole calcified layer of cartilage, a motorized drill for spinal surgery with a stop-mechanism, so that the depth drilled was exactly the same in all samples, was used. Thus, all defects had the same diameter $(6 \mathrm{~mm})$ and depth $(2 \mathrm{~mm})$ and involved the subchondral bone (osteochondral defects). During drilling, the area was infused with saline solution to cool the tissue and to avoid dehydration of articular cartilage due to the loss of synovial fluid during the surgical procedure. Finally, an abrasion of the subchondral bone plate was carried out using a $18 \mathrm{G}$ needle, to allow bleeding of the bottom of the defect and the consequent access of both autologous mesenchymal stem cells MSCs and growth factors from the underlying bone marrow. The left joint received the ES-like cells embedded in fibrin glue, while the right knee was left untreated to serve as a control. All animals received an antibiotic and

Table 4 Antibodies used for immunocytochemistry

\begin{tabular}{lllll}
\hline Antigens & Detected tissue & $\mathbf{I}^{\circ}$ Antibodies & Antibodies dilution & II $^{\circ}$ Antibodies \\
\hline SSEA-1 & Staminality Marker & Mc 480 & $1: 100$ & Anti-mouse IgM $^{c}$ \\
SSEA-3 & Staminality Marker & Mc 631 & $1: 100$ & Anti-rat IgM (Pierce Thermo Scientific) \\
SSEA-4 & Staminality Marker & Mc 813-70 & $1: 100$ & Anti-mouse lgG \\
Cytokeratin & Endoderm & Anti-cytokeratin peptide 18 & $1: 100$ & Anti-mouse IgG \\
Early mesoderm & Early mesoderm & Fe-C6 & $1: 100$ & Anti-mouse IgM \\
Embryonic myosin & Late mesoderm & F1-652 & $1: 100$ & Anti-mouse IgG \\
Neural precursor cells & Ectoderm & Forse-1 & $1: 100$ & Anti-mouse IgM \\
\hline
\end{tabular}


an antinflammatory agent (amoxicillin $25 \mathrm{mg} / \mathrm{kg}$ im and ketoprofen $2 \mathrm{mg} / \mathrm{kg} \mathrm{im}$ ) before the patella was repositioned and the wound sutured. All surgical procedures were performed by the same operator, respecting animal welfare laws. Antibiotic and antinflammatory therapy (amoxicillin $40 \mathrm{mg} / \mathrm{kg} /$ day im and ketoprofen $2 \mathrm{mg} / \mathrm{kg} /$ day im) was administered for 5 days. All animals were kept confined in paddocks for 10 days in groups of 6 animals each, and then were allowed to roam freely on pasture for the rest of the study.

\section{Gross assessment}

Immediately after euthanasia, the defects were photographed to allow the assessment by 2 blinded observers. A semi-quantitative scoring system, developed by the International Cartilage Repair Society (ICRS), (Additional file 1: Table S1) was used and the values obtained were averaged. Observations were initially recorded as percentages (surface appearance, filling of the defect, and graft-host integration at the margins). These percentages were converted to scores from $0-3$ for purposes of statistical analysis.

\section{Histological and immunohistochemistry procedures and evaluation}

Samples containing regenerated tissue, adjacent host cartilage and subchondral bone (thickness: $0.5 \mathrm{~cm}$; width: 2-3 cm; height: $1-2 \mathrm{~cm}$; distance of cuts from edges of defect: $0.2 \mathrm{~cm}$ ) were harvested using a water-cooled circular saw. The tissue blocks were fixed in $10 \%$ neutralbuffered formalin and then decalcified with a 1:1 citric acid/formic acid solution for about 10 days. After washing in running tap water for $4-8 \mathrm{~h}$ to remove all traces of decalcification solution, samples were routinely processed for paraffin embedding. Three $\mu \mathrm{m}$ sections were mounted on positively charged slides (Superfrost Plus, Gerhard Menzel $\mathrm{GmbH}$ ) to prevent detachment and stained with hematoxylin-eosin for general tissue evaluation, Azan-Mallory to demonstrate collagen fibres and safranine-O to detect proteoglycans. All slides were processed together to avoid variability. Immunohistochemistry was used to detect collagen type II in the cartilage matrix. After deparaffinization, re-hydration, protease K and Endo- and Tissue-Blocker (Biomeda) treatments, slide were incubated overnight at $4^{\circ} \mathrm{C}$ with a primary antibody (anti-Collagen type II CIICI - DSHB) at 1:200 dilution, followed by the secondary biotinylated antibody (Biomeda) for $10 \mathrm{~min}$ at room temperature (R.T.), and by $3 \%$ peroxidase solution for 10 min at RT. After staining with diaminobenzidine (Biomeda) and counterstaining with haematoxylin, slides were dehydrated, coverslipped, observed under light microscopy and digital images were captured. The lateral femoral condyle was used as positive (articular cartilage) and negative (subchondral bone) controls.
Two independent observers evaluated the regeneration progress using a grading system developed by the authors and derived from Caplan [87] (Additional file 1: Table S2) and the 2 values obtained for each sample were averaged. A total score of 5 indicated the worst possible healing, while 56 indicated the best.

\section{FISH technique}

FISH assay was performed on one sample from each period, as previously described [88], using the DNA probe 50 bp in length (biotin-5 AAAGGGAGGGAGAGACCAAAGAAGTAGATGATGATGATGATGAAGTGATC 3') built on the SRY sequence. To assess the effectiveness of the probe, a membrane Dot-Blot test had been previously performed on the ES-like cell samples, using male and female fibroblasts as positive and negative controls, respectively. Sections mounted on positively charged slides (Superfrost Plus, Gerhard Menzel GmbH), were deparaffinised, rehydrated, permeabilized by $0.8 \%$ pepsin treatment at $37^{\circ} \mathrm{C}$ for $30 \mathrm{~min}$, post-fixed and incubated with a prehybridization solution ( $50 \%$ hybridization solution, $43 \%$ formamide and $7 \%$ double-distilled water) at $50^{\circ} \mathrm{C}$ for $2 \mathrm{~h}$. The probe $(2000 \mathrm{ng} / \mu \mathrm{l})$ was denatured at $98^{\circ} \mathrm{C}$ for $10 \mathrm{~min}$ and immediately placed on ice. Tissue was denaturated at $98^{\circ} \mathrm{C}$ for 8 min with $200 \mu \mathrm{l}$ of hybridization solution $(50 \%$ hybridization solution, $43 \%$ formamide, $1 \%$ probe and $6 \%$ double-distilled water). Hybridization was performed at $50^{\circ} \mathrm{C} \mathrm{o} / \mathrm{n}$ in a humid chamber. After SSPE washings at decreasing concentration, endogenous phosphatases were blocked by incubation with a blocking solution $(500 \mu \mathrm{l}$ of $2 \%$ BSA, $3 \mu \mathrm{l}$ of $0.3 \%$ Triton X-100, $500 \mu \mathrm{l}$ of PBS) for $45 \mathrm{~min}$ at RT. The chromogen reaction was developed by incubation with Extravidin-TRITC-conjugated for $2 \mathrm{~h}$ at RT in the dark. Slides were counterstained with Hoechst, mounted with an aqueous medium, coverslipped, sealed with nail polish, observed under a fluorescent confocal microscope and images recorded. All slides were processed together, including the right lateral femoral condyle as a negative control.

\section{Statistical analysis}

An analysis of variance was performed on the macroscopic and histological data from the total as well as selected category scores of both groups throughout all time periods. The model of the analysis contained the main effects of treatment and time from surgery and the interaction between them, together with the random effect of the ewe within the period. The Mixed Procedure of SAS 8.2 (SAS Institute Inc., Cary, NC, USA) was used to perform the analysis.

\section{Availability of supporting data}

All the supporting data are included as additional files. 


\section{Additional files}

\section{Additional file 1: Provided with this submission, shows the semi-quantitative macroscopic and histological scores for the samples' evaluation and the tables of least square means of macroscopic and histological scores for each time period (1, 2, 6, 12 and 24 months).}

Additional file 2: ARRIVE checklist.

\section{Abbreviations}

ED: Empty defect; ESCs: Embryonic stem cells; ES-like cells: Embryonic stem-like cells; ES: ES-like cells engrafted in the medial femoral condyle defect; FISH: Fluorescent in situ hybridization; GFP: Green fluorescent protein; ICM: Inner cell mass; mAbs: monoclonal antibodies; MSCs: Mesenchymal stem cells; SAT: Sheep SAT 1,114 DNA repeat unit; SRY: Sex-determining region $Y$-linked gene sequence.

\section{Competing interests}

The authors declare that they have no competing interests.

\section{Authors' contributions}

SP: carried out the ES-like cell production, the histological and immunohistological assays, the FISH assays, prepared cells for engraftment: participated in the design of the study, data collection, assembly, analysis and interpretation, drafted the manuscript; SR: participated in the design of the study, data analysis and interpretation, helped to draft the manuscript; RRP: was responsible for the data analysis and interpretation, approved the final manuscript; MD: conceived the study, participated in its coordination and helped to draft the manuscript; LM: carried out the in vitro embryos production; DS: carried out the molecular genetic studies; SC: performed the statistical analysis; GM: carried out the animal surgery, helped to draft the manuscript; MLM: carried out the animal surgery; AM: conceived the study, participated in its coordination, carried out the animal surgery; ESP: conceived the study, participated in its coordination, carried out the animal surgery. All authors read and approved the final version of the manuscript.

\section{Acknowledgements}

The authors thank Dr. Debbie Gillette for reading and improving the manuscript and Mr. Giampiero Camoglio, Mr. Antonio Pintadu and Mr. Salvatore Pirastru for assistance in the care and management of animals. This work was funded by the MIUR (Ministry of Education, University and Research) in PRIN 2005. The funders had no role in study design, data collection and analysis, decision to publish, or preparation of the manuscript.

\section{Author details}

'Department of Animal Science, Agricultural Research Agency of Sardinia, Olmedo, Sassari 07040, Italy. '2Department of Veterinary Medicine, via Vienna, Sassari 07100 , Italy. ${ }^{3}$ Department of Veterinary Pathobiology, College of Veterinary Medicine and Biomedical Sciences, Texas A\&M University, College Station 77843-4467 TX, USA. ${ }^{4}$ Department of Surgery, Microsurgery and Medicine, University of Sassari, viale San Pietro, Sassari 07100, Italy.

Received: 23 May 2014 Accepted: 11 December 2014

Published online: 19 December 2014

\section{References}

1. Grassel S, Ahmed N: Influence of cellular microenvironment and paracrine signals on chondrogenic differentiation. Front Biosci 2007, 12:4946-4956.

2. Steinert AF, Ghivizzani SC, Rethwilm A, Tuan RS, Evans CH, Nöth U: Major biological obstacles for persistent cell-based regeneration of articular cartilage. Arthritis Res Ther 2007, 9:213-228.

3. Frenkel S, Di Cesare P: Degradation and repair of articular cartilage. Front Biosci 1999, 4:671-685.

4. Akens MK, von Rechenberg B, Bittmann P, Nadler D, Zlinszky K, Auer JA: Long-term in vivo studies of photo-oxidized osteochondral transplant in sheep. BMC Muskoloskel Disord 2001, 2:9-20.

5. Butnariu-Ephrat M, Robinson D, Mendes DG, Halperin N, Nevo Z Resurfacing of goat articular cartilage by chondrocytes derived from bone marrow. Clin Orthop 1996, 330:234-243.
6. Mano JF, Reis RL: Osteochondral defects: present situation and tissue engineering approaches. J Tissue Engin Reg Med 2007, 1:261-273.

7. Jackson DW, Scheer MJ, Simon TM: Cartilage substitutes: overview of basic science and treatment options. J Am Acad Orthop Surg 2001 9(Suppl 1):37-52.

8. Buckwalter JA, Mankin HJ: Articular cartilage repair and transplantation. Arthritis Rheum 1998, 41:1331-1342.

9. Shapiro F, Koide S, Glimcher MJ: Cell origin and differentiation in the repair of full-thickness defects of articular cartilage. J Bone Joint Surg Am 1993, 75:532-553.

10. Friedman M, Berasi C, Fox J, Del Pizzo W, Snyder S, Ferkel R: Preliminary results with abrasion arthroplasty in the osteoarthritic knee. Clin Orthop 1984, 82:200-205.

11. Gill TJ, Asnis PD, Berkson EM: The treatment of articular cartilage using the microfracture technique. J Orthop Sports Phys Ther 2006, 36(Suppl. 10):728-738.

12. Insall J: The Pridie debridement operation for osteoarthritis of the knee. Clin Orthop Relat Res 1974, 101:61-67.

13. Waselau AC, Nadler D, Müller JMV, Zlinszky K, Hilbe M, Auer JA, Von Rechenberg B: The effect of cartilage and bone density of mushroom shaped, photooxidized, osteochondral transplants: an experimental study on graft performance in sheep using transplants originating from different species. BMC Muskoloskelet Disord 2005, 6:60-71.

14. Frosch KH, Drengk A, Krause P, Viereck V, Miosge N, Werner C, Schild D, Stürmer EK, Stürmer KM: Stem cell-coated titanium implants for the partial joint resurfacing of the knee. Biomaterials 2006, 27:2542-2549.

15. Martinez-Carranza N, Berg HE, Hultenby K, Nurmi-Sandh H, Ryd L, Lagerstedt AS: Focal knee resurfacing and effects of surgical precision on opposing cartilage. A pilot study on 12 sheep. Osteoarthritis Cartilage 2013, 21(Suppl. 5):739-745

16. Dattena M, Pilichi S, Rocca S, Mara L, Casu S, Masala G, Manunta L, Manunta A, Passino ES, Pool RR, Cappai P: Sheep embryonic stem-like cells transplanted in full-thickness cartilage defects. J Tissue Eng Regen Med 2009, 3:175-187.

17. Undale AH, Westendorf JJ, Yaszemski MJ, Khosla S: Mesenchymal stem cells for bone repair and metabolic bone diseases. Mayo Clin Proc 2009, 84(Suppl 10):893-902.

18. Wilke MM, Daryl VN, Nixon AJ: Enhanced early chondrogenesis in articular defects following arthroscopic mesenchymal stem cell implantation in an equine model. J Orthop Res 2007, 25(Suppl 7):913-925.

19. Matzumoto T, Okabe T, Ikawa, Miosge N, Hartmann M, Maelicke C, Herken R Expression of collagen type I and type II in consecutive stages of human osteoarthritis. Histochem Cell Biol 2004, 122:229-236.

20. Murphy JM, Dixon K, Beck S, Fabian D, Feldman A, Barry F: Reduced chondrogenic and adipogenic activity of mesenchymal stem cells from patients with advanced osteoarthritis. Arthritis Rheum 2002, 46:704-713.

21. Murphy JM, Fink DJ, Hunziker EB, Barry FP: Stem cell therapy in a caprine model of osteoarthritis. Arthritis Rheum 2003, 48:3464-3474.

22. Van Osch GJVM, Brittberg M, Dennis JE, Bastiaansen-Jenniskens YM, Erben RG, Konttinen YT, Luyten FP: Cartilage repair: past and future - lessons for regenerative medicine. J Cell Mol Med 2009, 13(Suppl. 5):792-810.

23. Gillogly SD, Myers TH, Reinold MM: Treatment of large full-thickness chondral defects of the knee with autologous chondrocyte implantation. Arthroscopy 2003, 19:147-153.

24. Minas T, Chiu R: Autologous chondrocyte implantation. Am J Knee Surg 2000, 13:41-50.

25. Brittberg M, Lindahl A, Nilsson A, Ohlsson C, Isaksson O, Peterson L: Treatment of deep cartilage defects in the knee with autologous chondrocyte transplantation. New Engl J of Med 1994, 331(Suppl. 14):889-895.

26. Toh WS, Lee EH, Cao T: Potential of human embryonic stem cells in cartilage tissue engineering and regenerative medicine. Stem Cell Rev and Rep 2011, 7:544-559.

27. Schnabel M, Marlovits S, Eckhoff G, Fichtel I, Gotzen L, Vécsei V, Schlegel J: Dedifferentiation-associated changes in morphology and gene expression in primary human articular chondrocytes in cell culture. Osteoarthritis Cartilage 2002, 10(Suppl. 1):62-70.

28. Von der Mark K, Gauss V, von der Mark H, Müller P: Relationship between cell shape and type of collagen synthesized as chondrocytes lose their cartilage phenotype in culture. Nature 1977, 267(Suppl. 5611):531-532. 
29. Matzumoto T, Okabe T, Ikawa T, lida T, Yasuda H, Nakamura H, Wakitani S: Articular cartilage repair with autologous bone marrow mesenchymal cells. J Cell Physiol 2010, 225(Suppl. 2):291-295

30. Wakitani S, Goto T, Pineda SJ, Young RG, Mansour JM, Caplan Al, Goldberg VM: Mesenchymal cell-based repair of large, full-thickness defects of articular cartilage. J Bone Joint Surg 1994, 76:579-592.

31. Javazon EH, Beggs KJ, Flake AW: Mesenchymal stem cells: paradoxes of passaging. Exp Hematol 2004, 32(Suppl. 5):414-425.

32. Di Nicola M, Carlo-Stella C, Magni M, Milanesi M, Longoni PD, Matteucci P, Grisanti S, Gianni AM: Human bone marrow stromal cells suppress T-lymphocyte proliferation induced by cellular or non -specific mitogenic stimuli. Blood 2002, 99(Suppl. 10):3838-3843.

33. Bartholomew A, Sturgeon C, Siatskas M, Ferrer K, McIntosh K, Patil S, Hardy W, Devine S, Ucker D, Deans R, Moseley A, Hoffman R: Mesenchymal stem cells suppress lymphocyte proliferation in vitro and prolong skin graft survival in vivo. Exp Hematol 2002, 30(Suppl. 1):42-48.

34. Payne KA, Didiano DM, Chu CR: Donor sex and age influence the chondrogenic potential of human femoral bone marrow stem cells. Osteoarthritis Cartilage 2010, 18(Suppl. 5):705-713.

35. Toh WS, Lee EH, Guo XM, Chan JK, Yeow CH, Choo AB, Cao T: Cartilage repair using hyaluronan hydrogel-encapsulated human embryonic stem cellderived chondrogenic cells. Biomaterials 2010, 31(Suppl. 27):6968-6980.

36. Hwang NS, Varghese S, Elisseeff J: Derivation of chondrogenicallycommitted cells from human embryonic cells for cartilage tissue regeneration. PLoS One 2008, 3(Suppl. 6):e2498.

37. Toh WS, Yang Z, Liu H, Heng BC, Lee EH, Cao T: Effects of culture conditions and bone morphogenetic protein 2 on extent of chondrogenesis from human embryonic stem cells. Stem Cells 2007 25(Suppl. 4):950-960

38. Thomson JA, Itskovitz-Eldor J, Shapiro SS, Waknitz MA, Swiergiel JJ, Marshall VS, Jones JM: Embryonic stem cell lines derived from human blastocysts. Science 1998, 282(Suppl. 5391):1145-1147.

39. Wakitani S, Takaoka K, Hattori T, Miyazawa N, Iwanaga T, Takeda S, Watanabe TK, Tanigami A: Embryonic stem cells injected into the mouse knee joint form teratomas and subsequently destroy the joint. Rheumatology 2003, 42:162-165.

40. Wakitani S, Aoki H, Harada Y, Sonobe M, Morita Y, Mu Y, Tomita N, Nakamura Y, Takeda S, Watanabe TK, Tanigami A: Embryonic stem cell form articular cartilage, not teratomas, in osteochondral defects of rat joints. Cell Transp/ 2004, 13:331-336.

41. Prokhorova TA, Harkness LM, Frandsen U, Ditzel N, Schrøder HD, Burns JS, Kassem M: Teratoma formation by human embryonic stem cells is site-dependent and enhanced by the presence of matrigel. Stem Cells Dev 2008, 18(Suppl. 1):47-54

42. Talbot NC, Blomberg LA: The pursuit of ES cell lines of domesticated ungulates. Stem Cell Rev 2008, 4(Suppl. 3):235-254.

43. Mainil-Varlet $P$, Aigner $T$, Brittberg M, Bullough $P$, Hollander A, Hunziker $E$, Kandel R, Nehrer S, Pritzker K, Roberts S, Stauffer E: Histological assessment of cartilage repair: a report by the histology endpoint committee of the international cartilage repair society. J Bone Joint Surg Am 2003, 85:45-57.

44. Ude CC, Sulaiman SB, Min-Hwei N, Hui-Cheng C, Ahmad J, Yahaya NM, Saim $A B$, Idrus RB: Cartilage regeneration by chondrogenic induced adult stem cells in osteoarthritic sheep model. PLoS One 2014, 9(Suppl. 6):e98770.

45. Caminal M, Moll X, Codina D, Rabanal RM, Morist A, Barrachina J, Garcia F, Pla A, Vives J: Transitory improvement of articular cartilage characteristics after implantation of polylactide:polyglycolic acid (PLGA) scaffolds seeded with autologous mesenchymal stromal cells in a sheep model of critical-sized chondral defect. Biotechnol Lett 2014 36(Suppl. 10):2143-2153

46. Caminal M, Fonseca C, Peris D, Moll X, Rabanal RM, Barrachina J, Codina D, García F, Cairó JJ, Gòdia F, Pla A, Vives J: Use of a chronic model of articular cartilage and meniscal injury for the assessment of long-term effects after autologous mesenchymal stromal cell treatment in sheep. N Biotechnol 2014, 31(Suppl. 5):492-498.

47. Power J, Hernandez P, Guehring H, Getgood A, Henson F: Intraarticular injection of rhFGF-18 improves the healing in microfracture treated chondral defects in an ovine model. J Orthop Res 2014, 32(Suppl. 5):669-676.

48. Endres M, Neumann K, Zhou B, Freymann U, Pretzel D, Stoffel M, Kinne RW Kaps C: An ovine in vitro model for chondrocyte-based scaffold-assisted cartilage grafts. J Orthop Surg Res 2012, 7:37.
49. Ivkovic A, Pascher A, Hudetz D, Maticic D, Jelic M, Dickinson S, Loparic M, Haspl M, Windhager R, Pecina M: Articular cartilage repair by genetically modified bone marrow aspirate in sheep. Gene Ther 2010, 17(Suppl. 6):779-789.

50. Mrugala D, Bony C, Neves N, Caillot L, Fabre S, Moukoko D, Jorgensen C, Noël D: Phenotypic and functional characterization of ovine mesenchymal stem cells: application to a cartilage defect model. Ann Rheum Dis 2008, 67:288-295.

51. Seedhom BB, Luo ZJ, Goldsmith AJ, Toyoda T, Lorrison JC, Guardamagna L: In-situ engineering of cartilage repair: a pre-clinical in-vivo exploration of a novel system. Proc Inst Mech Eng H 2007, 221(Suppl. 5):475-488.

52. Von Rechenberg B, Akens MK, Nadler D, Bittmann P, Zlinszky K, Kästner SBR, Auer JA: Mosaicplasty with photooxidized, mushroom-shaped, bovine, osteochondral xenografts in experimental sheep. Vet Comp Orthop Traumatol 2006, 3:147-156.

53. Jiang CC, Chiang H, Liao CJ, Lin YJ, Kuo TF, Shieh CS, Huang YY, Tuan RS: Repair of porcine articular cartilage defect with a biphasic osteochondral composite. J Orthop Res 2007, 25(Suppl. 10):1277-1290.

54. Hunziker EB, Kapfinger $E$ : Removal of proteoglycans from the surface of defects in articular cartilage transiently enhances coverage by repair cells. J Bone Joint Surg Br 1998, 80(Suppl. 1):144-150.

55. Wakitani S, Kimura T, Hirooka A, Ochi T, Yoneda M, Yasui N, Owaki H, Ono K: Repair of rabbit articular surfaces with allograft chondrocytes embedded in collagen gels. J Bone Joint Surg 1989, 71(Suppl. 1):74-80.

56. Vasara Al, Hyttinen MM, Lammi MJ, Lammi PE, Långsjö TK, Lindahl A, Peterson L, Kellomäki M, Konttinen YT, Helminen HJ, Kiviranta I: Subchondral bone reaction associated with chondral defect and attempted cartilage repair in goats. Calcif Tissue Int 2004, 74:107-114.

57. Taylor SD, Tsiridis E, Ingham E, Jin Z, Fisher J, Williams S: Comparison of human and animal femoral head chondral properties and geometries. Proc Inst Mech Eng H 2012, 226(Suppl. 1):55-62.

58. Schneider-Wald B, von Thaden AK, Schwarz ML: Defect models for the regeneration of articular cartilage in large animals. Orthopade 2013, 42(Suppl. 4):242-253.

59. Von Rechenberg B, Akens MK, Nadler D, Bittmann P, Zlinszky K, Neges K, Auer JA: The use of photooxidized, mushroom-structured osteochondral grafts for cartilage resurfacing - a comparison to photooxidized cylindrical grafts in an experimental study in sheep. Osteoarthritis Cartilage 2004, 12:201-216.

60. Anderson JA, Little D, Toth AP, Moorman CT 3rd, Tucker BS, Ciccotti MG, Guilak F: Stem cell therapies for knee cartilage repair: the current status of preclinical and clinical studies. Am J Sports Med 2014, 42(Suppl. 9):2253-2261.

61. Mara L, Pilichi S, Sanna A, Accardo C, Chessa B, Chessa F, Dattena M, Bomboi G, Cappai P: Sexing of in vitro produced ovine embryos by duplex PCR. Mol Reprod Dev 2004, 69:35-42.

62. Nakajima M, Wakitani S, Harada Y, Tanigami A, Tomita N: In vivo mechanical condition plays an important role for appearance of cartilage tissue in ES cell transplanted joint. J Orthop Res 2008, 26(Suppl 1):10-17.

63. Keefer $C L$, Pant D, Blomberg $L$, Talbot NC: Challenges and prospects for the establishment of embryonic stem cells lines of domesticated ungulates. Anim Reprod Sci 2006, 98(Suppl. 1-2):147-168.

64. Solter D, Knowles BB: Monoclonal antibody defining a stage-specific mouse embryonic antigen (SSEA-1). Proc Natl Acad Sci U S A 1978, 75(Suppl. 11):5565-5569

65. Dattena M, Chessa B, Lacerenza D, Accardo C, Pilichi S, Mara L, Chessa F, Vincenti L, Cappai P: Isolation, culture and characterization of embryonic cell lines from vitrified sheep blastocysts. Mol Reprod Dev 2005, 73(Suppl 1):31-39.

66. Kannagi R, Cochran NA, Ishigami F, Hakomori S, Andrews PW, Knowles BB, Solter D: Stage-specific embryonic antigens (SSEA-3 and -4) are epitopes of a unique globo-series ganglioside isolated from human teratocarcinoma cells. EMBO J 1983, 2(Suppl. 12):2355-2361.

67. Resnick JL, Bixler LS, Cheng L, Donovan PJ: Long-term proliferation of mouse primordial germ cells in culture. Nature 1992, 359(Suppl. 6395):550-551.

68. Sanna D, Sanna A, Mara L, Pilichi S, Mastinu A, Chessa F, Pani L, Dattena M: Oct4 expression in in-vitro-produced sheep blastocysts and embryonicstem-like cells. Cell Biol Int 2009, 34(Suppl 1):53-60.

69. Okamoto K, Okazawa H, Okuda A, Sakai M, Muramatsu M, Hamada H: A novel octamer binding transcription factor is differentially expressed in mouse embryonic cells. Cell 1990, 60(Suppl. 3):461-472. 
70. Chambers I, Colby D, Robertson M, Nichols J, Lee S, Tweedie S, Smith A: Functional expression cloning of Nanog, a pluripotency sustaining factor in embryonic stem cells. Cell 2003, 113:643-655.

71. Avilion AA, Nicolis SK, Pevny LH, Perez L, Vivian N, Lovell-Badge R: Multipotent cell lineages in early mouse development depend on SOX2 function. Genes Dev 2003, 17:126-140.

72. Niwa H, Burdon T, Chambers I, Smith A: Self-renewal of pluripotent embryonic stem cells is mediated via activation of STAT3. Gene Dev 1998, 12:2048-2060.

73. Fenderson BA, Eddy EM, Hakomori S: The blood group I antigen defined by monoclonal antibody $\mathrm{C} 6$ is a marker of early mesoderm during murine embryogenesis. Differentiation 1988, 38(Suppl. 2):124-133.

74. Cho M, Webster SG, Blau HM: Evidence for myoblast-extrinsic regulation of slow myosin heavy chain expression during muscle fiber formation in embryonic development. J Cell Biol 1993, 121(Suppl. 4):795-810.

75. Tole S, Kaprielian Z, Ou SK, Patterson PH: FORSE-1: a positionally regulated epitope in the developing rat central nervous system. J Neurosci 1995, 15(Suppl. 2):957-969.

76. Tremoleda JL, Forsyth NR, Khan NS, Wojtacha D, Christodoulou I, Tye BJ, Racey SN, Collishaw S, Sottile V, Thomson AJ, Simpson AH, Noble BS, McWhir J: Bone tissue formation from human embryonic stem cells in vivo. Cloning Stem Cells 2008, 10(Suppl. 1):119-132.

77. Hurtig MB, Fretz PB, Doige CE, Schnurr DL: Effects of lesion size and location of equine articular cartilage repair. Can J Vet Res 1987, 52:137-146.

78. Schleicher I, Lips KS, Sommer U, Schappat I, Martin AP, Szalay G, Schnettler R: Allogenous bone with collagen for repair of deep osteochondral defects. J Surg Res 2013, 185(Suppl. 2):667-675.

79. Kim SH, Turnbull J, Guimond S: Extracellular matrix and cell signaling: the dynamic cooperation of integrin, proteoglycan and growth factor receptor. J Endocrin 2011, 209:139-151.

80. Poole AR: An introduction to the pathophysiology of osteoarthritis. Front Biosci 1999, 4:662-670.

81. Buckwalter JA, Mankin HJ: Articular cartilage. Part I: tissue design and chondrocyte-matrix interactions. Instr Course Lect 1998, 47:477-486.

82. Matyas JR, Adams ME, Huang D, Sandell L: Discoordinate gene expression of aggrecan and type II collagen in experimental osteoarthritis. Arthritis Rheum 1995, 38(Suppl 3):420-425.

83. Prockop DJ, Kivirikko Kl, Tuderman L, Guzman NA: The biosynthesis of collagen and its disorders (first of two parts). N Engl J Med 1979, 301(Suppl 1):13-23.

84. Bullough $P G$, Jagannath $A$ : The morphology of the calcification front in articular cartilage. J Bone Joint Surg 1983, 65(Suppl. 1):72-78.

85. Kuhn NZ, Tuan RS: Regulation of stemness and stem cell niche of mesenchymal stem cells: implications in tumorigenesis and metastasis. J Cell Physiol 2010, 222(Suppl. 2):268-277.

86. Dattena M, Mara L, Ali A, Cappai P: Lambing rate of vitrified blastocysts is improved by embryo culture with BSA and hyaluronan. Mol Reprod Dev 2007, 74(Suppl 1):42-47.

87. Caplan Al, Elyaderani M, Mochizuki Y, Wakitani S, Goldberg VM: Principles of cartilage repair and regeneration. Clin Orthop 1997, 342:254-269.

88. Sanna E, Sanna MP, Loddo C, Sanna L, Mura M, Cadelano T, Leoni A: Endogenous jaagsiekte sheep retrovirus RNA is expressed by different cell types in ovine fetus and placenta. Eur J Histochem 2002, 46(Suppl 3):273-280.

\section{Submit your next manuscript to BioMed Central and take full advantage of:}

- Convenient online submission

- Thorough peer review

- No space constraints or color figure charges

- Immediate publication on acceptance

- Inclusion in PubMed, CAS, Scopus and Google Scholar

- Research which is freely available for redistribution 